\title{
Struktur Komunitas Makrozoobenthos Sebagai Indikator Kualitas Perairan di Pantai Serangan Provinsi Bali
}

\author{
Yulihatul Meisaroh a*, I Wayan Restua , Dewa Ayu Angga Pebriani a \\ a Program Studi Manajemen Sumberdaya Perairan, Fakultas Kelautan dan Perikanan, Universitas Udayana, Bukit Jimbaran, Bali-Indonesia \\ * Penulis koresponden. Tel.: +62-85649248446 \\ Alamat e-mail: yulihatul.meisaroh@yahoo.com
}

Diterima (received) 16 September 2017; disetujui (accepted) 5 Februari 2018; tersedia secara online (available online) 6 Februari 2018

\begin{abstract}
Serangan Island is a small island located approximately $5 \mathrm{~km}$ in south of Denpasar City and has a maximum length of $2.9 \mathrm{~km}$ and a width of $1 \mathrm{~km}$ which is administratively as part of the Denpasar City, Bali Province. Serangan Island is widely used for aquaculture and fisheries activities, moreover Serangan is also used as tourism activities, transportation routes, the harbour of ships and residences which may have impact on the aquatic ecosystem balance. The purpose of this research is to know how the structure of macrozoobenthos community and the water quality condition in Serangan Island. The research was conducted on February to March 2017 by using descriptive quantitative method in 3 research stasions. The result showed that there are 23 species of macrozoobenthos that consists of 7 classes, namely Gastropods, Bivalve, Crustacea, Echinoidea, Asteroidea, Ophiuroidea, and Holothuroidea. The highest total of abundance was at station 1 about $46,8 \mathrm{ind} / \mathrm{m}^{2}$. The diversity index ranged from $0,66-2,14$ and the equibility index ranged from $0,60-0,81$, while the dominance index ranged from $0,17-0,63$. Based on the criteria of the Shanon-Wiener diversity index $\left(\mathrm{H}^{\prime}\right)$, the diversity index at station 1 and 2 indicates moderate diversity which has moderate species distribution and moderately polluted waters, whereas the value of the diversity index at station 3 indicates that the diversity in this stasion is low, showed by low abundance of species, low stability of the community and severe polluted condition.
\end{abstract}

Keywords: community structure; makrozoobenthos; Serangan Island

\begin{abstract}
Abstrak
Pulau Serangan merupakan pulau kecil yang terletak $5 \mathrm{~km}$ di sebelah selatan Kota Denpasar dan memiliki panjang maksimum 2,9 km serta lebar $1 \mathrm{~km}$ yang secara administratif pulau ini masih termasuk wilayah Kota Denpasar, Provinsi Bali. Pulau Serangan banyak dimanfaatkan untuk kegiatan perikanan budidaya dan perikanan tangkap, selain itu perairan Serangan juga dimanfaatkan sebagai kegiatan pariwisata, jalur transportasi kapal, pendaratan kapal serta pemukiman berpotensi menyebabkan terganggunya keseimbangan ekosistem perairan. Tujuan dari penelitian ini adalah untuk mengetahui struktur komunitas makrozoobenthos dan status kondisi kualitas air Pulau Serangan. Penelitian ini dilaksanakan pada bulan Pebruari-Maret 2017. Penelitian menggunakan metode deskriptif kuantitatif. Berdasarkan hasil penelitian yang dilaksanakan pada 3 stasiun didapatkan makrozoobenthos sebanyak 23 spesies yang terdiri 7 kelas, yaitu kelas Gastropoda, Pelecypoda, Crustacea, Echinoidea, Asteroidea, Ophiuroidea, Holothuroidea. Total kelimpahan tertinggi terdapat pada stasiun 1 yaitu 46,8 ind $/ \mathrm{m}^{2}$. Indeks keanekaragaman berkisar 0,66-2,14 dan indeks keseragaman berkisar 0,60-0,81, sedangkan indeks dominansi berkisar 0,17-0,63. Berdasarakan kriteria indeks keanekaragaman Shanon-Wiener $\left(\mathrm{H}^{\prime}\right)$, indeks keanekaragaman pada stasiun 1 dan 2 mengindikasikan keanekaragaman sedang yaitu penyebaran jumlah individu sedang dan keadaan perairan tercemar sedang, sedangkan nilai indeks keanekaragaman pada stasiun 3 mengindikasikan keanekaragaman rendah yaitu jumlah individu tiap spesies rendah dan tidak merata, kestabilan komunitas rendah dan keadaan tercemar berat.
\end{abstract}

Kata Kunci: makrozoobenthos; Pulau Serangan; struktur komunitas 


\section{Pendahuluan}

Ekosistem perairan pesisir di Indonesia merupakan wilayah yang akhir-akhir ini mendapat perhatian cukup besar dalam berbagai kebijaksanaan dan perencanaan pembangunan di Indonesia. Secara empiris wilayah pesisir merupakan tempat aktivitas ekonomi yang mencakup perikanan laut dan pesisir, transportasi dan pelabuhan, pertambangan, kawasan industri, pariwisata, kawasan pemukiman serta tempat pembuangan limbah. Berbagai aktivitas tersebut membuat kondisi perairan mengalami degradasi seperti adanya pencemaran yang mengakibatkan penurunan kualitas perairan (Rachmawaty, 2011).

Pengkajian kualitas perairan dapat dilakukan dengan pendekatan analisis fisika, kimia serta biologi. Untuk lingkungan perairan yang dinamis, analisis fisika dan kimia kurang memberikan gambaran yang sesungguhnya. Lingkungan yang dinamis lebih representatif menggunakan analisis biologi. Salah satu indikator biologi yaitu menggunakan analisis struktur komunitas makrozoobenthos. (Rachmawaty, 2011).

Faktor yang mendasari penggunaan hewan benthos khususnya makroozobenthos sebagai organisme indikator suatu perairan adalah karena benthos memiliki sifat yang relatif pasif atau memiliki mobilitas yang rendah. Dengan demikian makrozoobenthos akan tetap tinggal dalam paparan cemaran (pollutan) lingkungan yang tidak baik, sehingga memiliki kemampuan merespon kondisi kualitas air secara terus-menerus (Indarmawan dan Manan, 2011).

Daya toleransi benthos terhadap pencemaran bahan organik dapat dikelompokkan menjadi 3 yaitu jenis intoleran, jenis fakultatif, dan jenis toleran. Jenis Intoleran merupakan organisme yang tidak dapat beradaptasi bila kondisi perairan mengalami penurunan kualitas. Jenis fakultatif merupakan organisme yang dapat bertahan hidup di perairan yang banyak bahan organik, namun tidak dapat mentolerir tekanan lingkungan. Jenis toleran merupakan organisme yang sering dijumpai di perairan yang berkualitas buruk.

Pulau Serangan terletak $5 \mathrm{~km}$ di sebelah selatan Kota Denpasar yang secara administratif pulau ini masih termasuk wilayah Kota Denpasar, Provinsi Bali. Pulau Serangan banyak dimanfaatkan untuk berbagai kegiatan seperti perikanan budidaya dan perikanan tangkap. Selain itu perairan Serangan juga dimanfaatkan sebagai kegiatan pariwisata, pelabuhan kapal, jalur transportasi kapal, pendaratan kapal serta pemukiman (Ernawati dan Dewi, 2016). Adanya berbagai kegiatan tersebut dapat berpotensi menyebabkan terganggunya keseimbangan ekosistem perairan termasuk kualitas perairan. Hal ini juga akan mempengaruhi kondisi biota yang berada di perairan khususnya makroozobenthos.

Berdasarkan kondisi di atas sangat penting dilakukan penelitian mengenai struktur komunitas makroozobenthos sebagai indikator kualitas perairan Pulau Serangan, karena sejauh ini belum pernah dilakukan penelitian mengenai makroozobenthos sebagai indikator kualitas perairan di Pulau Serangan.

Tujuan dari penelitian ini yaitu untuk mengetahui struktur komunitas perairan Pulau Serangan dan untuk mengetahui status kondisi kualitas perairan di Pulau Serangan.

\section{Metode Penelitian}

\subsection{Waktu dan Lokasi Penelitian}

Penelitian struktur komunitas makroozoobenthos sebagai indikator dilaksanakan di Pulau Serangan Provinsi Bali. Penelitian ini dilaksanakan pada bulan Pebruari - Maret 2017. Pengambilan sampel dilakukan pada 3 stasiun yaitu area pantai, budidaya rumput laut, dan mangrove. Lokasi Penelitian dan stasiun pengambilam sampel makrozoobenthos dapat dilihat pada Gambar 1.

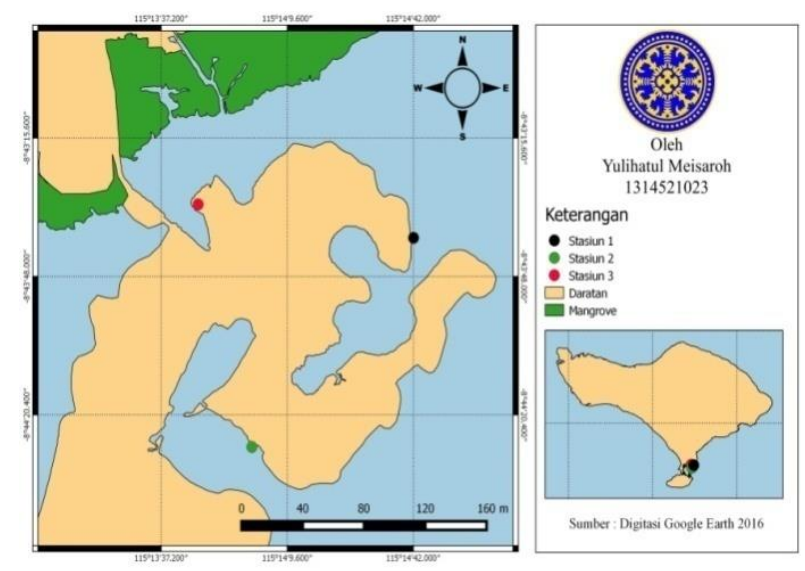

Gambar 1. Peta Lokasi Penelitian

\subsection{Alat dan Bahan}

Alat dan bahan yang digunakan dalam penelitian ini yaitu DO meter, $\mathrm{pH}$ pen, turbidity, GPS, transek kuadrat 1x1 m, nampan, plastik, tali, kertas label, cool box, peralatan tulis, nampan, kamera, penjepit, 
panduan buku identifikasi. Sedangkan bahan yang digunakan yaitu aquades, Formalin, sampel makrozoobenthos.

\subsection{Prosedur Penelitian}

\subsubsection{Penentuan Stasiun}

Penentuan lokasi penelitian dilakukan dengan menggunakan metode purposive sampling, dimana pada penelitian ini terdapat tiga stasiun dan pada masing-masing stasiun terdapat 3 titik pengambilan sampel. Jarak antar titik yaitu $20 \mathrm{~m}$ ke arah laut. Penjelasan pada setiap stasiun adalah sebagai berikut:

a. Stasiun 1 berada di pantai serangan atau pantai timur yang diperuntukkan untuk kegiatan pariwisata, surfing, banana boat dll.

b. Stasiun II terletak pada pantai yang terdapat budidaya rumput laut

c. Stasiun III terletak di sekitar area mangrove

\subsubsection{Pengambilan Sampel}

Pengambilan sampel makroozobenthos dilakukan 3 kali selama 2 bulan dengan menggunakan metode deskriptif kuantitatif. Pengambilan sampel makrozoobenthos dilakukan pada setiap stasiun yang telah ditentukan pada saat kondisi surut, alat yang digunakan adalah japit dan serok serta transek kuadrat berukuran $1 \times 1 \mathrm{~m}$ sebagai plot. Sampel makrozoobenthos yang telah diambil diletakkan terlebih dahulu di nampan kemudian di masukkan ke kantong plastik dan diberi tanda, setelah diberi tanda sampel disimpan di cool box. Sesudah pengambilan sampel makrozoobenthos, sampel dikeluarkan dari cool box dan dilakukan pengawetan menggunakan formalin, kemudian dilakukan identifikasi sampel di Laboratorium Ilmu Perikanan Fakultas Kelautan dan Perikanan Universitas Udayana.

\subsubsection{Parameter Kualitas Air}

Pameter kualitas air yang diukur dalam penelitian ini yaitu parameter fisika-kimia, meliputi: Suhu, $\mathrm{pH}$, salinitas, DO (oksigen terlarut), dan kekeruhan.

\subsection{Analisis Data}

\subsubsection{Kelimpahan Makrozoobenthos}

Kelimpahan makrozoobenthos dihitung dengan menggunakan rumus menurut Brower et al. (1990).
$D=\frac{n i}{A}$

dimana $D$ adalah kelimpahan individu (ind/ $\mathrm{m}^{2}$ ); ni adalah jumlah individu jenis ke-i yang diperoleh; dan $A$ adalah luas total area pengambilan contoh $\left(\mathrm{m}^{2}\right)$.

\subsubsection{Indeks Keanekaragaman}

Indeks keanekaragaman dihitung dengan rumus Shanon-Wiener (Setiawan, 2009) yaitu:

$H^{\prime}=-\sum_{i=1}^{s} p i \ln p i$

dimana $H^{\prime}$ adalah indeks keanekaragaman; S adalah jumlah jenis; $p i$ adalah ni/N; $n i$ adalah jumlah individu jenid ke-i; dan $N$ adalah jumlah total individu semua jenis.

Kriteria indeks keanekaragaman Shanon-Wiener $\left(\mathrm{H}^{\prime}\right)$ menurut Setiawan (2009) mempunyai kisaran nilai tertentu yaitu sebagai berikut:

$\mathrm{H}^{\prime}<1$ : Keanekaragaman spesiesnya rendah, jumlah individu tiap spesies rendah, kestabilan komunitas rendah dan keadaan tercemar berat

$1<\mathrm{H}^{\prime}<3$ : Keanekaragaman sedang, penyebaran jumlah individu tiap spesies sedang dan keadaan perairan tercemar sedang.

$\mathrm{H}^{\prime}>3$ : Keanekaragaman tinggi, penyebaran jumlah individu tiap spesies tinggi dan perairan belum tercemar.

\subsubsection{Indeks Keseragaman}

Indeks keseragaman dihitung dengan rumus menurut Krebs (1989) dalam Fajri (2013) yaitu:

$E=\frac{H^{\prime}}{\ln S}$

dimana $E$ adalah indeks keseragaman; $H^{\prime}$ adalah indeks keseragaman; dan $S$ adalah jumlah semua jenis.

Kriteria indeks keseragaman menurut Brower et al. (1990) sebagai berikut:

$\mathrm{E}<0,4 \quad$ : Tingkat keseragaman rendah

$0,4<\mathrm{E}<0,6 \quad$ : Tingkat keseragaman sedang

$\mathrm{E}>0,6 \quad:$ Tingkat keseragaman tinggi

\subsubsection{Indeks Dominansi}

Indeks dominansi menggunakan rumus menurut (Odum, 1993) yaitu:

$C=\sum\left[\frac{n i}{N}\right]^{2}$ 
dimana $C$ adalah indeks dominansi; $n i$ adalah jumlah individu ke-i; dan $N$ adalah jumlah total individu.

Kriteria indeks dominansi menurut Odum (1993) sebagai berikut:

$$
\begin{array}{ll}
0<\mathrm{C}<0,3 & \text { : Dominansi rendah } \\
0,3<\mathrm{C}<0,6 & \text { : Dominansi sedang } \\
0,6<\mathrm{C}<1 & \text { : Dominansi tinggi }
\end{array}
$$

\section{Hasil dan Pembahasan}

\subsection{Kekayaan Jenis Makrozoobenthos}

Komunitas makrozoobenthos yang ditemukan di perairan Serangan terdiri dari 23 jenis dengan jumlah 175 individu. Komunitas makrozoobenthos ini didukung oleh 3 phylum dan 7 kelas. 3 phylum tersebut terdiri dari Moluska, Arthropoda, dan Echinodermata sedangkan 7 kelas terdiri dari Gastropoda, Bivalvia, Crustacea, Echinoidea, Asteroidea, Ophioroidea, dan Holothuroidea (Tabel 1).

\section{Tabel 1}

Makrozoobenthos yang ditemukan

\begin{tabular}{ll}
\hline \multicolumn{1}{c}{ Kelas } & \multicolumn{1}{c}{ Spesies } \\
\hline & Tectus sp. \\
& Gibberuslus gibberulus \\
& Conus sp. \\
& Nerita sp. \\
& Clympeamorus inflata \\
Gastropoda & Turritriton sp. \\
& Cerithideopsilla cingulata \\
\hline \multirow{2}{*}{ Bivalvia } & Anadara sp. \\
& Leukoma staminea \\
\hline \multirow{5}{*}{ Crustacea } & Portunus sp. \\
& Dardanus sp. \\
& Grapsus sp. \\
& Clibanarius sp. \\
& Uca sp. \\
& Coenobita sp. \\
\hline \multirow{2}{*}{ Echinoidea } & Deadema setosum \\
& Echinometra mathaei \\
\hline Asteroidea & Holopneustes porosissimus \\
\hline \multirow{3}{*}{ Ophiuroidea } & Echinaster luzonicus \\
& Ophiarachna incrassate \\
\hline Holothuroidea & Ophiomastix annulosa \\
\hline & Ophiocoma sp. \\
\hline & Holothuria sp. \\
\hline
\end{tabular}

\subsection{Kelimpahan Makrozoobenthos}

Kelimpahan total makrozoobenthos mulai stasiun 1 hingga stasiun 3 diperoleh kelimpahan tertinggi pada stasiun 1 yaitu sebesar 46,8 ind/ $/ \mathrm{m}^{2}$ (Tabel 2), hal ini diduga karena faktor fisika-kimia perairan stasiun 1 lebih baik dari pada stasiun lainnya. Selain itu, diduga juga dipengaruhi oleh substrat perairan, pada stasiun 1 substrat dasar perairan berupa pasir berbatu, batu kerikil yang terdapat pecahan karang, lamun serta alga. Substrat tersebut merupakan yang paling banyak ditemukannya makrozoobenthos karena substrat pasir serta pecahan karang dapat menjadi tempat perlindungan makrozoobenthos dari arus. Hal tersebut didukung oleh pernyataan Fadli et al. (2012) bahwa substrat dasar yang berupa batubatu kerikil merupakan substrat yang mendukung untuk makrozoobenthos karena dapat berlindung dari gerakan arus. Selain itu, Lamun juga merupakan habitat bagi makrozoobenthos untuk mencari makan,berlindung dari arus dan predator (Hitalessy et al., 2015), sehingga pada padang lamun banyak ditemukannya makrozoobenthos. Hal tersebut juga didukung oleh pernyataan Fredriksen et al. (2010) bahwa organisme yang ditemukan di padang lamun dua kali lebih banyak dibandingkan dengan daerah yang tidak memiliki lamun. Kadar parameter fisika-kimia Stasiun 1 tidak ada yang kurang atau lebih dari nilai optimum sehingga makrozoobenthos dapat melangsungkan kehidupannya dengan baik.

Nilai kelimpahan terendah terdapat pada stasiun 2 yaitu sebesar 21,6 ind $/ \mathrm{m}^{2}$, hal ini diduga pada stasiun 2 memiliki substrat pasir berlumpur yang menyebabkan makrozoobenthos sulit untuk berlindung dari arus, sesuai dengan pernyataan Koesbiono (1979) mengatakan bahwa dasar perairan berupa pasir berlumpur merupakan lingkungan hidup yang kurang baik untuk hewan benthos. Adanya beberapa parameter kualitas air yang nilainya tidak optimal, terdapat sedikit lamun di daerah budidaya rumput laut serta aktivitas manusia, yaitu seringnya warga sekitar mengambil biota laut juga diduga mempengaruhi terhadap tinggi rendahnya kelimpahan makrozoobenthos.

Stasiun 3 nilai kelimpahan lebih tinggi dibandingkan dengan stasiun 2. Hal tersebut karena dipengaruhi oleh adanya beberapa parameter kualitas perairan yang tidak sesuai dengan nilai optimum serta terdapat spesies yang mendominasi di stasiun 3 yaitu Cherithideopsilla cingulata yang merupakan spesies jenis toleran yang habitatya hanya di area mangrove, sehingga nilai kelimpahan lebih tinggi dibandingkan dengan stasiun 2 . 
Tabel 2.

Kelimpahan makrozoobenthos semua stasiun

\begin{tabular}{lcccc}
\hline \multirow{2}{*}{ Nama Spesies } & \multicolumn{3}{c}{ Stasiun } & \multirow{2}{*}{ Jumlah } \\
\cline { 2 - 4 } Tectus sp. & 0,6 & - & - & 0,6 \\
Gibberuslus sp. & 1,8 & - & - & 1,8 \\
Conus sp. & 1,8 & - & - & 1,8 \\
Nerita sp. & - & 1,8 & - & 1,8 \\
Clympeamorus inflata & - & 7,2 & - & 7,2 \\
Turritriton sp. & - & 1,8 & - & 1,8 \\
Cerithideopsilla cingulata & - & - & 28,2 & 28,2 \\
Anadara sp. & 1,2 & - & - & 1,2 \\
Leukoma staminea & 0,6 & - & - & 0,6 \\
Portunus sp. & 0,6 & 0,6 & - & 1,2 \\
Dardanus sp. & 0,6 & - & - & 0,6 \\
Grapsus sp. & - & 0,6 & - & 0,6 \\
Clibanarius sp. & - & 2,4 & 7,2 & 9,6 \\
Uca sp. & - & - & 1,8 & 1,8 \\
Coenobita sp. & 13,8 & 6,6 & - & 20,4 \\
Deadema setosum & 10,2 & - & - & 10,2 \\
Echinometra mathaei & 1,8 & - & - & 1,8 \\
Holopneustes porosissimus & 2,4 & - & - & 2,4 \\
Echinaster luzonicus & 1,8 & - & - & 1,8 \\
Ophiarachna incrassata & 1,2 & - & - & 1,2 \\
Ophiomastix annulosa & 1,2 & - & - & 1,2 \\
Ophiocoma sp. & 7,2 & - & - & 7,2 \\
Holothuria sp. & - & 0,6 & - & 0,6 \\
\hline Jumlah Spesies & 15 & 8 & 3 & 23 \\
Kelimpahan Total & 46,8 & 21,6 & 36,6 & 105 \\
\hline
\end{tabular}

\subsection{Indeks Keanekaragaman}

Hasil perhitungan indeks keanekaragaman menunjukkan indeks tertinggi terdapat pada stasiun 1 dengan nilai 2,14, pada stasiun 2 sebesar 1,69 dan indeks terendah terdapat pada stasiun 3 dengan nilai 0,66 (Gambar 2). Indeks keanekaragaman tinggi diduga disebabkan oleh jumlah spesies yang didapatkan cukup banyak sehingga tidak ada spesies yang mendominasi pada stasiun 1 . Tingginya keanekaragaman juga dipengaruhi oleh adanya keadaan ekologi. Dimana pada stasiun 1 keadaan ekologi sekitar terbilang cukup bagus karena nilai parameter kualitas air tidak terjadi penurunan kualitas dan memiliki substrat pasir, batu kerikil, lamun dan alga.

Indeks keanekaragaman pada stasiun 3 rendah diduga disebabkan oleh jumlah spesies yang didapatkan sedikit dan terdapat satu spesies yang mendominasi. Rendahnya indeks keanekaragaman dipengaruhi oleh adanya faktor lingkungan sekitar sehingga terjadi penurunan kualitas air. Pada stasiun 3 merupakan area mangrove yang disekitarnya terdapat banyak buangan sampah masyarakat yang menyebabkan terjadinya penurunan kualitas perairan. Pada stasiun 3 nilai DO kurang dari nilai optimum yaitu 3,6 mg/l, nilai tersebut akan menyebabkan terganggunya kehidupan dan pertumbuhan suatu organisme yang tinggal di area tersebut. Selain DO, kekeruhan juga melebihi dari batas optimum yaitu 10,5 NTU.

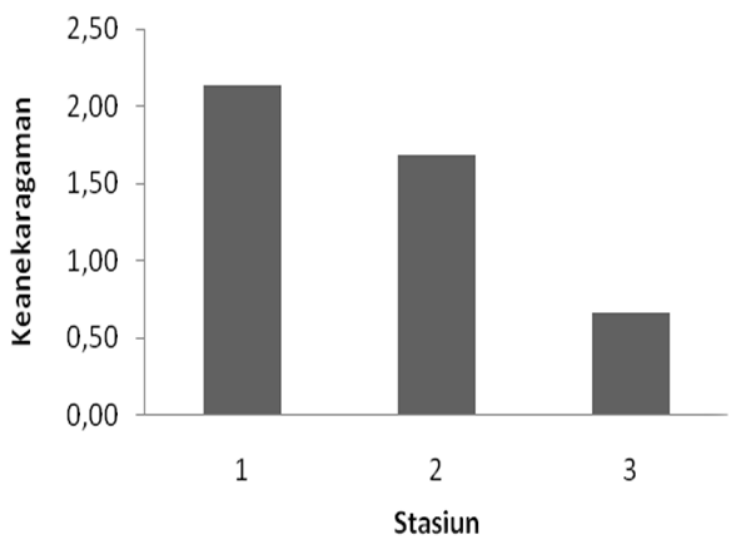

Gambar 2. Indeks Keanekaragaman Makrozoobenthos

Menurut Iswanti et al. (2012) nilai indeks keanekaragaman dapat digunakan sebagai pendugaan kondisi lingkungan perairan. Pada stasiun 1 nilai indeks keanekaragaman sebesar 2,14 stasiun 2 sebesar 1,69 dan stasiun 3 sebesar 0,66. Pada indeks keanekaragaman stasiun 1 dan 2 menunjukkan tingkat keanekaragaman sedang yaitu penyebaran jumlah individu sedang dan keadaan perairan tercemar sedang. Sedangkan nilai indeks keanekaragaman pada stasiun 3 menunjukkan tingkat keanekaragaman rendah yaitu jumlah individu tiap spesies rendah, kstabilan komunitas rendah dan keadaan tercemar berat. Hal tersebut sesuai dengan kriteria nilai indeks keanekaragaman Shanon-Wiener $\left(\mathrm{H}^{\prime}\right)$ menurut Setiawan (2009).

\subsection{Indeks Keseragaman}

Hasil perhitungan indeks keseragaman diperoleh pada stasiun 1 sebesar 0,79, pada stasiun 2 yaitu sebesar 0,81 yang menunjukkan indeks keseragaman tertinggi, dan pada stasiun 3 yaitu sebesar 0,60 yang menunjukkan indeks keseragaman terendah (Gambar 3).

Hasil perhitungan indeks keseragaman stasiun 1 dan stasiun 2 menunjukkan E lebih dari 0,60 yaitu sebesar 0,79 dan 0,81. Menurut tabel kategori 
indeks keseragaman oleh Brower et al. (1990), nilai tersebut menunjukkan tingkat keseragaman tinggi. Indeks keseragaman yang tinggi meununjukkan persebaran spesies makrozoobenthos merata. Hal tersebut juga didukung dengan nilai indeks dominasi kedua stasiun rendah.

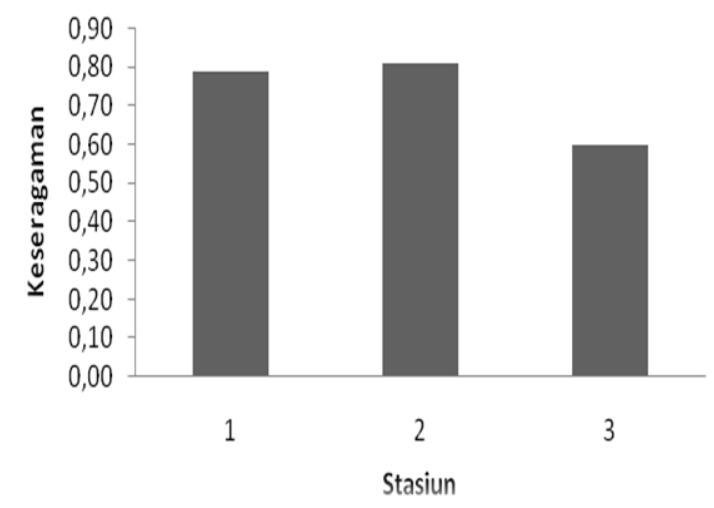

Gambar 3. Indeks Keseragaman Makrozoobenthos

Stasiun 3 memiliki nilai indeks keseragaman sebesar 0,60. Nilai tersebut menurut tabel kategori indeks keseragaman menunjukkan tingkat keseragaman sedang. Tingkat keseragaman yang sedang menunjukkan persebaran spesies makrozoobenthos kurang merata. Hal tersebut dipengaruhi juga oleh nilai indeks keanekaragaman yang rendah dan nilai indeks dominansi yang tinggi.

\subsection{Indeks Dominansi}

Hasil perhitungan indeks dominansi diperoleh pada stasiun 1 sebesar 0,17 yang menunjukkan indeks dominansi terendah, pada stasiun 2 yaitu sebesar 0,23, dan pada stasiun 3 yaitu sebesar 0,63 yang menunjukkan indeks keseragaman tertinggi (Gambar 4).

Stasiun 3 memiliki indeks dominansi tertinggi dibandingkan stasiun 1 dan stasiun 2 yaitu sebesar 0,63 . Menurut tabel kategori indeks dominansi Odum (1993), nilai indeks tersebut termasuk indeks dominansi yang tinggi atau terdapat jenis yang mendominasi. Tingginya nilai indeks dominansi dikarenakan jumlah spesies yang didapatkan rendah. Selain itu nilai kelimpahan yang didapatkan pada satu spesies cenderung tinggi dan mendominasi. Spesies yang mendominasi yaitu Certhideopsilla cingulata dimana jenis tersebut merupakan benthos bersifat toleran yaitu dapat bertahan hidup terhadap lingkungan yang tercemar berat.

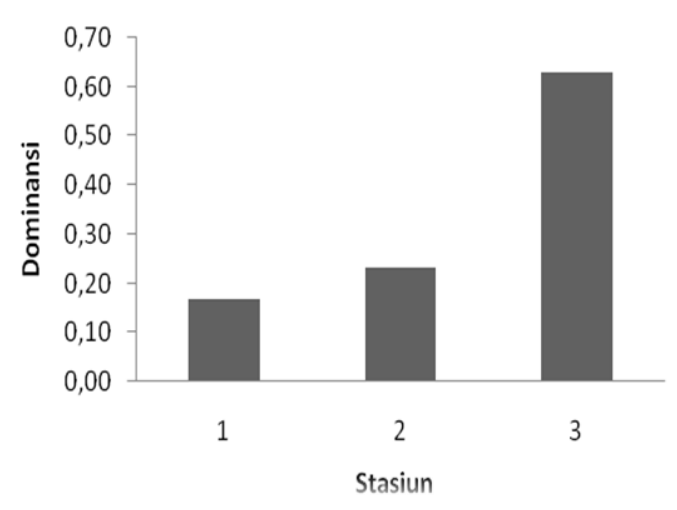

Gambar 4. Indeks Dominansi Makrozoobenthos

Pada Stasiun 1 dan 2 memiliki nilai indeks dominansi 0,17 dan 0,23 Menurut tabel kategori indeks dominansi apabila $0<\mathrm{C}<0,3$ maka nilai indeks dominansi rendah atau tidak ada jenis yang mendominasi, rendahnya indeks dominansi disebabkan spesies yang didapatkan lebih tinggi dibandingkan dengan stasiun 3.

\subsection{Parameter Kualitas Air}

Pengukuran parameter kuaitas air fisika-kimia pada ketiga stasiun meliputi $\mathrm{pH}, \mathrm{DO}$, salinitas, kekeruhan dan suhu, hasil pengukuran parameter kualitas air disajikan dalam Tabel 3.

\section{Tabel 3}

Nilai Rata-rata Kualitas Perairan

\begin{tabular}{lllll}
\hline \multirow{2}{*}{ No } & \multirow{2}{*}{ Parameter } & \multicolumn{3}{c}{ Stasiun } \\
\cline { 3 - 5 } & & \multicolumn{1}{c}{1} & \multicolumn{1}{c}{3} \\
\hline 1 & pH & 7,8 & 7,6 & 7,5 \\
2 & DO (mg/l) & 5,5 & 4,3 & 3,6 \\
3 & Salinitas (ppt) & 33 & 31 & 29,2 \\
4 & Kekeruhan (NTU) & 4,5 & 7,9 & 10,5 \\
5 & Suhu ( $\left.{ }^{\circ} \mathrm{C}\right)$ & 28,5 & 29 & 30 \\
\hline
\end{tabular}

Pengukuran parameter kualitas air dilakukan pada pagi hari, dimana intensitas cahaya matahari yang masuk ke dalam perairan masih rendah. Hasil pengukuran $\mathrm{pH}$ pada ketiga stasiun didapatkan nilai rata-rata tidak jauh berbeda yaitu berkisar 7,5-7,8. Nilai $\mathrm{pH}$ yang yg didapatkan pada stasiun 1 hingga stasiun 3 termasuk dalam kategeori normal, menurut Pratiwi (2010) nilai pH 
yang ideal bagi kehidupan organisme akuatik $\mathrm{pH}$ tidak kurang dari 5 dan tidak lebih dari 9 .

Hasil pengukuran DO pada ketiga stasiun didapatkan nilai DO tertinggi pada stasiun 1 sebanyak 5,5 mg/l, pada stasiun 2 sebanyak 4,3 $\mathrm{mg} / \mathrm{l}$, dan nilai terendah pada stasiun 3 yaitu 3,6 $\mathrm{mg} / \mathrm{l}$. Nilai DO pada stasiun 2 dan stasiun 3 kurang dari nilai optimum, hal ini terjadi diduga karena stasiun 2 substrat dasar berupa pasir berlumpur yang mudah tersuspensi, adanya substrat atau sedimen yang tersuspensi mengakibatkan kekeruhan serta terganggunya intensitas cahaya yang masuk ke dalam perairan, sehingga proses fotosintesis menjadi terhambat.

Stasiun 3 terjadi penurunan DO karena diduga pada stasiun 3 terdapat banyak buangan sampah atau limbah rumah tangga. Banyaknya sampah diikuti juga oleh banyaknya mikroorganisme, sehingga mikroorganisme tersebut membutuhkan banyak oksigen untuk melakukan penguraian. Menurut Ridwan et al. (2016) kehidupan makrozoobenthos dapat bertahan jika kandungan oksigen terlarut minimum sebanyak $5 \mathrm{mg} / \mathrm{l}$.

Hasil pengukuran salinitas didapatkan nilai berkisar 29,2-33 ppt. Nilai salinitas pada stasiun 1 hingga stasiun 3 masih termasuk dalam kategori normal. Menurut Sinyo dan Idris (2013) kisaran salinitas yang masih mampu mendukung kehidupan organisme perairan, khususnya fauna makrobenthos adalah 27 - 34 ppt.

Hasil pengukuran kekeruhan pada ketiga stasiun terjadi kenaikkan. Pada stasiun 1 nilai kekeruhan normal yaitu 4,5 NTU. Pada stasiun 2 nilai kekeruhan tinggi yaitu 7,9 NTU, hal ini terjadi karena stasiun 2 substrat dasar berupa pasir berlumpur yang mudah tersuspensi, adanya substrat atau sedimen dasar yang tersuspensi ini yang menyebabkan naiknya nilai kekeruhan. Stasiun 3 nilai kekeruhan juga mengalami kenaikkan yaitu 10,5 NTU, hal ini terjadi karena disekitarnya terdapat banyak buangan sampah atau limbah rumah tangga yang disebabkan oleh manusia. Menurut Indrayana et al. (2014), baku mutu kekeruhan untuk biota laut adalah tidak lebih dari 5 NTU.

Hasil pengukuran suhu pada ketiga stasiun tidak jauh berbeda dan masih dalam kisaran normal yaitu 28,5-30 ${ }^{\circ} \mathrm{C}$. Menurut Hasniar et al. (2013) suhu normal yang baik bagi kehidupan organisme laut perairan sekitar $26-32{ }^{\circ} \mathrm{C}$.

\section{Simpulan}

Berdasarkan penelitian yang telah dilakukan dapat disimpulkan bahwa, indeks keanekaragaman pada stasiun 1 dan 2 tergolong sedang dengan nilai indeks 2,14 dan 1,69, pada stasiun 3 tergolong rendah dengan nilai indeks 0,66. Indeks keseragaman stasiun 1 dan 2 tergolong tinggi dengan indeks 0,79 dan 0,81 , dan indeks keseragaman stasiun 3 tergolong sedang dengan indeks 0,60 . Indeks dominansi stasiun 1 dan 2 tergolong rendah yaitu 0,17 dan 0,23 yang menunjukkan tidak ada spesies yang mendominasi sedangkan pada stasiun 3 indeks dominansi tinggi yaitu 0,63 yang menunjukkan terdapat spesies yang mendominasi yaitu Certhideopsilla cingulata.

Kondisi kualitas perairan berdasarakan indeks keanekaragaman diperoleh bahwa pada stasiun 1 dan 2 mengindikasikan keanekaragaman sedang yaitu penyebaran jumlah individu sedang dan keadaan perairan tercemar sedang. Sedangkan pada stasiun 3 mengindikasikan tingkat keanekaragaman rendah yaitu jumlah individu tiap spesies rendah, kestabilan komunitas rendah dan keadaan perairan tercemar berat.

\section{Ucapan terimakasih}

Penulis mengucapkan terimakasih kepada kantor BTID yang telah memberikan ijin kepada penulis untuk melaksanakan penelitian di Pulau Serangan. Penulis mengucapkan terimakasih kepada Laboratorium Perikanan Uiversitas Udayana yang telah memberikan fasilitas dalam penyelesaian penelitian.

\section{Daftar Pustaka}

Brower, J., Jerrold, Z., \& Ende, C. V. (1990). Field and Laboratory Methods for Genera Zoology. (3 ${ }^{\text {rd }}$ ed). United States of America: W.M.C Brown Publishers.

Ernawati, N. M., \& Dewi, A. P. W. K. (2016). Kajian Kesesuaian Kualitas Air Untuk Pengembangan Keramba Jaring Apung di Pulau Serangan, Bali. Ecotrophic: Journal of Environmental Science, 10(1), 75-80.

Fadli, N., Setiawan, I., \& Fadhilah, N. (2012). Keragaman makrozoobenthos di perairan kuala gigieng Kabupaten Aceh Besar. DEPIK Jurnal Ilmu-Ilmu Perairan, Pesisir dan Perikanan, 1(1), 45-52.

Fajri, N. (2013). Struktur Komunitas Makrozoobenthos di Perairan Pantai Kuwang Wae Kabupaten Lombok Timur. Educatio, 8(2), 81-100. 
Fredriksen, S., De Backer, A., Boström, C., \& Christie, H. (2010). Infauna from Zostera marina L. meadows in Norway. Differences in vegetated and unvegetated areas. Marine biology research, 6(2), 189-200.

Hasniar, H., Litaay, M., \& Priosambodo, D. (2013). Biodiversitas Gastropoda di Padang Lamun Perairan Mara Bombang Kabupaten Pinrang Sulawesi Selatan. Torani (Jurnal Ilmu. Kelautan dan Perikanan), 23(3), 127136.

Hitalessy, R. B., Leksono, A. S., \& Herawati, E. Y. (2015). Struktur Komunitas Dan Asosiasi Gastropoda Dengan Tumbuhan Lamun di Perairan Pesisir Lamongan Jawa Timur. Jurnal Pembangunan dan Alam Lestari, 6(1), 64-73.

Indarmawan, T., \& Manan, A. (2011). Pemantauan Lingkungan Estuaria Perancak Berdasarkan Sebaran Makrzoobenthos. Jurnal Ilmiah Perikanan dan Kelautan, 3(2), 215-220.

Indrayana, R., Yusuf, M., \& Rifai, A. (2014). Pengaruh Arus Permukaan Terhadap Sebaran Kualitas Air di Perairan Genuk Semarang. Jurnal Oseanografi, 3(4), 651-659.

Iswanti, S., Ngabekt, S., \& Martuti, N. K. T. (2012). Distribusi dan Keanekaragaman Jenis Makrozoobentos di Sungai Damar Desa Weleri Kabupaten Kendal. Jurnal Life Science, 1(2), 86-93.
Koesbiono. (1979). Dasar-Dasar Ekologi Umum. Bogor, Indonesia: Fakultas Perikanan IPB Bogor.

Odum, E. P. (1993). Dasar-Dasar Ekologi Umum. Diterjemahkan oleh T. Samingan; Yogyakarta: Gadjah Mada University Press.

Pratiwi, R. (2010). Asosiasi Krustasea di ekosistem padang lamun perairan Teluk Lampung. ILMU KELAUTAN: Indonesian Journal of Marine Sciences, 15(2), 66-76.

Rachmawaty, R. (2011). Indeks Keanekaragaman Makrozoobenthos Sebagai Bioindikator Tingkat Pencemaran di Muara Sungai Jeneberang. Bionature, 12(2), 103-109.

Ridwan, M., Fathoni, R., Fatihah, I., \& Pangestu, D.A (2016). Struktur Komunitas makrozoobenthos di Empat Muara Sungai Cagar Alam Pulau Dua, Serang, Banten. Al-Kauniyah Jurnal Biologi, 9(1), 57-65.

Setiawan, D. (2009). Studi Komunitas Makrozoobenthos di Perairan Hilir Sungai Lematang Sekitar Daerah Pasar Bawah Kabupaten Lahat. Jurnal Penelitian Sains, 9, 12-14.

Sinyo, Y., \& Idris, J. (2013). Studi Kepadatan dan Keanekaragaman Jenis Organisme Bentos pada Daerah Padang Lamun di Perairan Pantai Kelurahan Kastela Kecamatan Pulau Ternate. Jurnal Bioedukasi, 2(1), 154-162.

(C) 2018 by the authors; licensee Udayana University, Indonesia. This article is an open access article distributed under the terms and conditions of the Creative Commons Attribution license (http://creativecommons.org/licenses/by/3.0/). 